Jurnal Pemikiran Konstruktif Bidang Filsafat dan Dakwah

ISSN $1907-0993$

E ISSN $2442-8264$

Vol. 16 No. 2, Desember 2019

\title{
PENDIDIKAN KEJIWAAN DAN KESEHATAN MENTAL (PERSPEKTIF FAKHRUDDIN AR-RAZI)
}

\author{
Muhammad Arif ${ }^{1}$ \\ ${ }^{1}$ IAIN Sultan Amai Gorontalo, muharif@ iaingorontalo.ac.id
}

\begin{abstract}
Abstarct: This article elaborates on Fakhruddin ar-Razi thougts about psychiatric and mental health. The research used a qualitative method. The findings showed that soul according to Fakhruddin ar-Razi, divided into three souls that are rational, emotional souls and animal. Furthermore, ar-Razi thoughts about Islamic mental health are love and romance, fairness, envy, anger, falsehood, miser and greed. All of these require Islamic therapy for healing.
\end{abstract}

Keyword: psychiatric, mental health, Fakhruddin ar-Razi

Abstrak: Artikel ini mengelaborasi tentang pemikiran Fakhruddin ar-Razi tentang kejiwaan dan kesehatan mental. Penelitian ini menggunakan metode kualitatif. Hasil temuan menunjukkan bahwa Jiwa menurut Fakhruddin ar-Razi, terbagi tiga: jiwa yang bersifat rasional, jiwa yang bersifat emosional dan kehewanan. Selanjutnya pemikiran al-Razi tentang kesehatan mental Islami adalah: cinta dan asmara, wujub, iri, kemarahan dan dusta, kikir dan tamak. Kesemuanya ini memerlukan terapi Islami untuk penyembuhannya.

Kata Kunci: Kejiwaan, Kesehatan Mental, Fahruddin ar-Razi 
Jurnal Pemikiran Konstruktif Bidang Filsafat dan Dakwah

ISSN $1907-0993$

E ISSN $2442-8264$

Vol. 16 No. 2, Desember 2019

\section{A. PENDAHULUAN}

Fakhruddin, nama lengkapnya adalah Abu Abdullah Muhammad bin Umar bin Husain bin Hasan bin Ali at-Taimi al-Bakri. Ia bergelar "Fakhruddin" yang dikenal dengan sebutan Ibnu Khatib ar-Ray. Dia seorang pembaharu Islam di penghujung abad ke-16 Hijriah, dan pemikir terbesar yang lahir setelah Imam alGhazali. ${ }^{1}$ Ia dilahirkan di Ray, sebuah kota yang terletak di bagian timur Teheran (Iran) pada tahun 544 Hijriah/1150 Masehi, tapi ada juga yang mengatakan pada tahun 543 Hijriyah. Ia hidup di tengah-tengah sebuah keluarga yang terkenal sangat mencintai ilmu dan keutamaan. Ayahnya adalah Syaikh adalah Syaikh Imam Dhiyauddin Umar Khathib ar-Ray, seorang guru dan khotib di kota Ray. Syaikh Imam Dhiyauddin memiliki berbagai karangan di bidang ilmu ushul, bimbingan dan penyuluhan dan lain sebagainya. Awal kesibukan Fakruddin adalah menimba ilmu dari orang tuanya ${ }^{2}$.

Abu Abdullah, Abu al-Fadhl Muhammad ibnu Umar ar Razi, atau lebih popular dengan nama Imam ar-Razi dan Fakhr ar-Razi, merupakan salah seorang ensiklopedis Islam terbesar di sepanjang masa. Sebagian kalangan bahkan menganggap beliau sebagai argumentator Islam (Hujjatul Islam), setelah Imam alGhazali. Dengan multi-telenta yang dimilikinya, beliau mampu menguasai berbagai bidang ilmu, seperti Filsafat, sejarah, matematika, astronomi, kedokteran, teologi dan tafsir. Bahkan di setiap bidangnya, ar-Razi mampu mengungguli pakar-pakar di zamannya. Karena kepakarannya, ia diperbolehkan menyandang gelar Syeik al-Islam. Karya-karya magnum-opus nya antara lain: At Tafsir al Kabir, Al Muhashashal, dan Lubab al Isyarat.

Ibnu Khalkan berkomentar tentang Fakhruddin ar-Razi. Dia seorang yang tak tertandingi di zamannya. Satu-satunya orang yang hebat dan melampaui orangorang sezamannya di bidang ilmu kalam, ilmu-ilmu rasional, ilmu tentang sejarah

\footnotetext{
${ }^{1}$ Fathullah Khalif, Fakhruddin ar-Razi, Iskandariah: Danal Jamiat al Mishriyah, 1977, h. 1, 6-7.

${ }^{2}$ Ibnu Khalkan, juz. 4, h. 252; Ibnu Ushabibah, h. 465; al-Qafithi, h.191.
} 
Jurnal Pemikiran Konstruktif Bidang Filsafat dan Dakwah

ISSN $1907-0993$

E ISSN $2442-8264$

Vol. 16 No. 2, Desember 2019

pendahulu, serta memiliki banyak karangan yang bermanfaat di berbagai bidang ilmu. Dia berjasa besar dalam mengembangkan ilmu tentang bimbingan dan penyuluhan dengan menggunakan bahasa Arab maupun non-Arab. Kata-katanya menggugah perasaan dan membuat orang menangis. Majelis pengajiannya yang ada di kota Hurah dihadiri oleh tokoh-tokoh berbagai mazhab dan aliran. Mereka bertanya kepadanya, lalu dia menjawab setiap pertanyaan dengan baik. Karena kehebatannya sejumlah besar pengikut kelompok Karamiyah dan lain-lain kembali ke mazhab Ahlusunnah. Di kota Hurah dia dijuluki Syaikhul Islam ${ }^{3}$.

Fakhruddin memiliki berbagai buku karangan tentang berbagai disiplin ilmu. Di antaranya tafsir, ilmu, di antaranya tafsir, ilmu kalam, ushul fiqih, hikmah, ilmu debat nahwu, sastra, kedokteran, teknik, psikologi, ilmu firasat, akhlak dan ilmu tentang aliran dan golongan ${ }^{4}$. Diperkirakan jumlah karangannya melebihi 200 buah. Adapun buku-buku penting yang berkaitan dengan psikologi adalah sebagai berikut: Kitab an Nafs ar-Ruh wa Syarh Quwahuma, ditahkikkan oleh Muhammad Shaghir Hasan al-Ma'shumi, Islamabad, Lembaga Kajian Islam, 1978. di dalam kata pengantar buku tersebut, Fakhruddin ar-Razi mengatakan, "Sesungguhnya buku ini berbicara tentang ilmu akhlak yang disusun berdasarkan metode al-burhain bukan dengan metode bahasa yang memuaskan. Di dalam buku itu, penulis memaparkan daya-daya jiwa dan terapi jiwa terhadap sifat-sifat tercela. Al-Mathalib al-Alisyah Min al'Ilm al Ilahi, juz 7 dari buku Fi al-Arwih al-Alisyah wa as Safilah (an-Nafs), Beirut : Dar'al-Kitab al-Arabi, 1978. Al-Farasah; Daliluka ila Ma 'rifat Akhlak an Nas wa Thaba'ihim wa Ka'annahum Daliluka Maftuh, ditakhikkan dan diberi komentar oleh Mustafa Asyura, Kairo: Maktabah al-Qur'an, 1987. Karya-karyanya: Tafsir al-Kabir (The Great Commentary) (juga dikenal sebagai Mafatih al-ghayb); Al-Bayan wa al-Burhan fi al-Radd 'ala Ahl al-Zaygh wa al-Tughyan; Al-Mahsul fi 'Ilm al-Ushul; Al-Mutakallimin fi 'Ilm al-Kalam; Ilm al-Akhlaq (Ilmu Etika); Kitab

\footnotetext{
${ }^{3}$ Ibnu Khalkan, juz, h. 248-250.
}

${ }^{4}$ Inu Khalkan, juz 4, h. 249; al-Qaftibi, h. 191-192; Khairuddin az-Zarkali, juz 6, h. 313. Lihat catatan lengkap tentang seluruh karangan Fakhruddin ar-Razi dalam lampiran buku an-Nafs wa ar-Ruh wa Syarh Quwahuma, karangan Fakruddin ar Razi, op. cit., h. 193-198. 
Jurnal Pemikiran Konstruktif Bidang Filsafat dan Dakwah

ISSN $1907-0993$

E ISSN $2442-8264$

Vol. 16 No. 2, Desember 2019

al-Firasa (Buku tentang Firasa); Kitab al-Mantiq al-Kabir (Major Book on Logika); Kitab al-nafs wa 1-ruh wa Sharh Quwa-huma (Buku tentang Jiwa dan Roh dan Fakultas mereka); Mabahith al-mashriqiyya fi 'ilm al-ilahiyyat wa-'l-tabi'iyyat (Studi Timur di Metafisika dan Fisika); Matalib al-'Aliya; Muhassal Afkar al-mutaqaddimin wa-'1-muta'akhkhirin (The Harvest / Kompendium dari Pemikiran of the Ancients dan Kaum modern); Nihayat al 'Uqul fi al-Ushul Dirayat; Risalah al-Huduth; Syarh alIsharat (Komentar pada Isharat); Syarh Asma 'Allah al-Husna (Commentary on Asma' Allah al-Husna); Syarh al-Qanun Kulliyyat fi al-Tibb (Commentary on Canon of Medicine); Syarh al-Wajiz Nisf li'l-Ghazali (Commentary on Nisf al-Wajiz AlGhazali); Syarh Uyun al-Hikmah (Commentary on Uyun al-Hikmah). ${ }^{5}$

\section{B. PEMBAHASAN}

Filsafat tentang jiwa (ruh), bermula dari sebuah pertanyaan yang timbul dari buah pikiran ar-Razi, yakni, sebuah pertanyaan tentang keabadian lain, setelah kematian? Keabadian lain itu adalah ruh yang akan selalu hidup, tetapi ruh bodoh. Materi juga kekal, karena kebodohannya ruh mencintai materi dan membuat banyak dirinya untuk memperoleh kebahagiaan materi. Tetapi materi menolak, akhirnya Tuhan ikut campur untuk membantu ruh. Dijadikan lapisan dari ruh, yakni sebuah jasad yang beragam macam. Kemudian Tuhan menciptakan sebuah jasad yang sempurna, itulah manusia yang berguna untuk menggerakkan aktivitas di dunia ini. Dalam filsafatnya mengenai hubungan manusia dengan Tuhan, ia dekat kepada filsafat Pythagoras, yang memandang kesenangan manusia sebenarnya ialah kembali kepada Tuhan dengan meninggalkan alam materi ini. Untuk kembali ke Tuhan, maka roh harus lebih dahulu disucikan dan yang dapat menyucikan roh adalah ilmu pengetahuan dan membuat pantangan dalam mmengerjakan beberapa hal tanpa dasar ilmu. Menurut ar-Razi jalan mensucikan roh adalah falsafat. Manusia harus menjauhi kesenangan yang dapat diperoleh hanya dengan menyakiti orang lain atau yang

\footnotetext{
${ }^{5}$ Biografi Fakhr ad-Din ar-Razi - Filsuf Muslim, https://biografi-tokohternama.blogspot.com/2015/03/biografi-fakhr-ad-din-ar-razi-filsuf-muslim.html
} 


\section{FARABI}

Jurnal Pemikiran Konstruktif Bidang Filsafat dan Dakwah

ISSN $1907-0993$

E ISSN $2442-8264$

Vol. 16 No. 2, Desember 2019

bertentangan dengan rasio. Tetapi sebaliknya, manusia jangan pula sampai tidak makan atau berpakaian, tetapi makanlah dan berpakaian sekedar untuk memelihara diri.

Pandangan Fakhruddin ar-Razi tentang Kejiwaan dan Kesehatan Mental Fakhr al-Din ar-Razi juga mengatakan bahwa jiwa bisa juga dibuktikan secara empiris, yang berbeda dengan tubuh dan bagian-bagian tubuh dengan beberapa alasan: pertama, Jiwa bukanlah himpunan bagian-bagian tubuh karena penglihatan tidak menghimpun seluruh kerja tubuh. Kedua, jiwa juga tidak identik dengan bagian dari tubuh karena tidak ada dari bagian tubuh yang meliputi semua kerja tubuh. Ketiga, jika kita melihat sesuatu, kita mengetahuinya, setelah itu menyukainya ataupun membencinya, mendekatinya ataupun menjauhinya. Jika penglihatan adalah sesuatu, dan pengetahuan adalah sesuatu yang lain, maka yang melihat tidak akan mengetahui. Padahal, ketika saya melihat, saya mengetahui. Jadi, esensi dari penglihatan dan pengetahuan adalah satu. Keempat, semua bagian tubuh adalah alat untuk jiwa. Jiwa melihat dengan mata, berfikir dengan otak, berbuat dengan hati, merasa dengan kulit, dan seterusnya. ${ }^{6}$ Selanjutnya terdapat beberapa pemikiran Fakruddin ar-Razi:

1. Tabiat Jiwa

Fakhruddin ar-Razi mendefinisikan jiwa sebagai suatu substansi yang berbeda dengan badan, terpisah secara esensial dan bergantung dengannya secara pengaturan dan intruksi. Anggota badan merupakan perangkat dan alat bagi jiwa. Sebagaimana tukang kayu mengerjakan berbagai pekerjaan dengan perantara berbagai alat. ${ }^{7}$ Fakhruddin ar-Razi mendefinisikan jiwa sebagai suatu substansi yang berbeda dengan badan, terpisah secara esensial dan bergantung dengannya. Secara pengaturan dan instruksi. Anggota badan merupakan perangkat dan alat bagi jiwa. Sebagaimana tukang kayu mengerjakan berbagai pekerjaan dengan perantara berbagai alat, maka demikian pula jiwa, ia melihat dengan mata, mendengar dengan

\footnotetext{
${ }^{6}$ http://digilib.uinsby.ac.id/14424/4/Bab\%201.pdf

7 https://www.referensimakalah.com/2012/08/konsep-jiwa-menurut-ar-Razi.html
} 
Jurnal Pemikiran Konstruktif Bidang Filsafat dan Dakwah

ISSN $1907-0993$

E ISSN $2442-8264$

Vol. 16 No. 2, Desember 2019

telinga, berpikir dengan otak, dan bertindak dengan hati. Oleh karena itu, semua anggota badan itu merupakan alat bagi jiwa ${ }^{8}$. Ar-Razi membicarakan tentang al-Nafs Mutmainnah adalah jiwa yang mengenal-Nya atau ma'rifatullah karena selalu beribadah kepada-Nya. ${ }^{9}$

Jiwa tidak bersifat fisik, sebab ia merupakan substansi yang bebas dari sifat fisik. Fakhruddin ar-Razi menyebutkan beberapa bukti yang telah disebutkan Ibnu Sina terdahulu bahwa jiwa bukanlah fisik. Dia pernah berkata, "Sesungguhnya mazhab Jumhur dari kalangan penganut ilmu hakikat dan mukasyafah menyebutkan bahwa hati adalah pemimpin absolut bagi semua anggota badan. Pertama-tama, jiwa melakukan kontak dengannya, dan melalui kontak itu, jiwa mengalami kontak dengan seluruh anggota badan. Itulah mazhab Aristoteles dan pengikutnya dari berbagai kalangan ahli hikmah.

Fakhruddin ar-Razi membuktikan hal tersebut secara burhani dengan berbagai dalil yang bersumber dari al-Qur'an, akhbar (Istilah dalam ilmu hadis) dan argumen-argumen rasional.

\section{Daya Jiwa}

Fakhruddin tidak mengungkapkan hal baru tentang jiwa, tetapi dia mendasarkan pendapatnya tentang jiwa dari Ibnu Sina. Dia berpendapat bahwa jiwa memiliki tiga macam daya, yaitu daya tumbuh-tumbuhan, daya hewani dan daya insani. Daya-daya jiwa manusia meliputi daya berpikir dan merasa serta daya untuk berbuat. Daya-daya inilah yang membuat manusia dapat bergerak dan melakukan berbagai jenis perbuatan. Unsur ini pula yang menjadi unsur penentu (decision maker) dari perbuatan dan tindakan manusia, yang pada akhirnya menentukan nilai kemanusiaan pada individu yang bersangkutan. ${ }^{10}$ Peranan Fakhruddin ar-Razi dalam pengembangan keilmuan Islam tidak dapat dilepaskan dari perhatian yang diberikan penguasa paada saat itu, ketika Fakhruddin ar-Razi meninggalkan Khawarizmi

\footnotetext{
${ }^{8}$ Kitab an Nafs wa ar-Ruh wa Syarh Quwahuma, op cit., h. 32-33.

${ }^{9}$ Abd. Jalaluddin, Ketenangan Jiwa menurut Fahr al-Din ar-Razi dalam Tafsir Mafatih alGhayb, (Jakarta: Sekolah Tinggi Filsafat Islam Sadra Jakarta, 2018), h. 38.

${ }^{10}$ https://alusttadz.blogspot.com/2012/05/daya-daya-jiwa-manusia.html
} 
Jurnal Pemikiran Konstruktif Bidang Filsafat dan Dakwah

ISSN $1907-0993$

E ISSN $2442-8264$

Vol. 16 No. 2, Desember 2019

menuju Transoksania (Asia tengah), ia disambut hangat penguasa dinasti Guri, Giyatuddin, dan saudaranya, Syihabuddin. Hanya saja, keadaan semacam ini tidak berjalan lama, karena ia mendapat serangan tajam dari golongan Karamiyah. ${ }^{11}$

Pemikiran Fakhruddin ar-Razi bahwa jiwa dan bukan tubuh yang mengatur tubuh sangat penting untuk direnungkan. Kita mungkin banyak menghabiskan uang untuk berobat, merawat kesehatan badan, menjaga tubuh dengan membeli berbagai produk kesehatan dan kosmetika, dan membeli pakaian dengan berbagai merek, model dan bentuk. Jika tidak menghabiskan banyak uang untuk keperluan dan keinginan tersebut, setiap hari kita mandi untuk membersihkan tubuh kita. Namun, apakah jiwa yang justru mengatur tubuh kita juga dibersihkan, diobati, dirawat dan dihiasi ${ }^{12}$

B. Daya Insani

\section{Pengertian}

a) Iman

Jika manusia memiliki dua daya, yaitu daya teoretis dan daya praktis. Daya teoretis adalah daya yang karenanya substansi jiwa siap untuk menerima gambargambar yang bersifat universal dan abstrak, sedangkan daya praktis adalah daya yang karenanya substansi jiwa siap mengatur badan dan memperbaiki tugas-tugasnya. ${ }^{13}$

\section{Daya Praktis}

Daya praktis adalah daya rasional yang dengannya jiwa mengatur badan dan memperbaiki kepentingannya. Sebab, jiwa memasuki alam fisik untuk memperoleh ilmu yang bermanfaat dan amal salih. Alat jiwa dalam memperolehnya adalah jiwa. Jika alatnya tidak baik, maka orang yang berusaha memperolehnya tidak akan pernah memperolehnya. Sedangkan daya akal praktis adalah yang mengatur urusan badan

\footnotetext{
${ }^{11}$ kajian tokoh: Biografi Fakhruddin Ar-Razi, karya-karyanya dan metologi Tafsir Mafatihul Ghaib, From: https://belajartafsirhadis.blogspot.com/2015/03/kajian-tokoh-biografifakhruddin-al.html

${ }^{12}$ Muhammad Akbar, Jiwa Manusia menurut Fakhruddin ar-Razi, From: https://mujahiddakwah.com/2018/09/jiwa-manusia-menurut-fakhruddin-ar-Razi-adnin-armas-m-a/

${ }^{13}$ Kitab an-Nafs wa Syarkh Quwahuma, h. 77.
} 


\section{FARABI}

Jurnal Pemikiran Konstruktif Bidang Filsafat dan Dakwah

ISSN $1907-0993$

E ISSN $2442-8264$

Vol. 16 No. 2, Desember 2019

dan memperbaiki kepentingannya agar menjadi alat yang baik bagi jiwa dalam memperoleh ilmu yang bermanfaat dan amal yang salih ${ }^{14}$, atau sebagaimana yang dikatakan ar-Razi dengan istilah lain, agar jiwa memperoleh indahnya ilmu, terlukis oleh lukisan alam malaikul, dan berhiaskan hiasan lahut. ${ }^{15}$

Fakhruddin ar-Razi menyebutkan beberapa contoh yang menjelaskan adanya anggota badan dan berbagai daya jiwa yang melayani jiwa rasional. Di antara contoh tersebut adalah bahwa badan seperti kota, jiwa rasional seperti raja, indera batin maupun batin seperti pasukan, tentara anggota badan seperti rakyat, syahwat dan kemarahan seperti musuh yang menyerang kerajaan dan berusaha menghancurkan rakyat. Jika raja ingin menindas musuh, maka kerajaan akan kokoh dan permusuhan akan hilang, tetapi jika raja tidak melawan musuhnya, maka kerajaannya akan hancur, negerinya diduduki, dan akibat akhirnya adalah kehancuran. $^{16}$

Contoh lain adalah bahwa perumpamaan jiwa rasioal seperti penunggang kuda yang ingin berburu. Syahwat sebagai mangsanya, dan kemarahannya sebagai anjingnya. Jika penunggang kuda tersebut seorang yang cerdas, maka kudanya akan taat dan patuh, serta anjingnya terlatih, sehingga ia pasti menuai kesuksesan. Tetapi jika ia seorang yang dungu, kudanya liar dan anjingnya tidak terdidik, maka kudanya tidak akan pernah menuruti perintahnya tidak akan mengikuti bimbingannya sehingga ia akan menuai kegagalan ketimbang mendapatkan apa yang ia cari ${ }^{17}$. Agaknya, contoh tersebut juga pernah dipaparkan Miskawaih sebelumnya.

3. Kesatuan jiwa

Fakhruddin ar-Razi mengkritik para filosof yang berpendapat adanya pembagian berbagai aksi jiwa berdasarkan berbagai daya, dan penyadaran setiap aksi

\footnotetext{
${ }^{14}$ Ibid., h. 286, Kitab an-Nafs wa ar-Ruh wa Syarh Quwaham, h. 80.

${ }^{15}$ Al-Matholib al-Aliyah min al-Ilm al-Ilahi, juz 7, h. 288, Kitab an-Nafs wa ar-Ruh wa Syarh Quwahuma, h. 82-83.

${ }^{16}$ Al-Mathalib-al-Aliyah Min al-ilm al-Ilahi juz 7, h. 287, kitab wa arRu-h wa-Syarh Quwahuma, h. 81.

${ }^{17}$ Al-Mathalib al-Aliyah Min al-ilm al-Ilahi juz 7, h. 286, kitab wa ar-Ruh wa-Syarh Quwahuma, h. 81-82.
} 


\section{FARABI}

Jurnal Pemikiran Konstruktif Bidang Filsafat dan Dakwah

ISSN $1907-0993$

E ISSN $2442-8264$

Vol. 16 No. 2, Desember 2019

secara tajam pada satu daya. Dia mengatakan bahwa seluruh proses persepsi adalah milik substansi jiwa, semua aksi adalah milik substansi jiwa, dan setiap anggota badan adalah alat jiwa sesuai dengan aksinya yang khusus. Sehingga, alat jiwa untuk melihat adalah mata, untuk mendengar adalah telinga, dan untuk berbicara adalah $\operatorname{lidah}^{18}$.

Fakhruddin ar-Razi mengkritik Galenos yang berpendapat tentang adanya tiga jiwa, yaitu jiwa rasional yang berpusat pada otak, jiwa emosi yang berpusat di hati, dan jiwa syahwat yang berpusat pada jantung. Menurut Fakhruddin, pendapat yang benar adalah pendapat Aristoteles yang mengatakan bahwa jiwa itu satu, lalu darinya muncul berbagai daya jiwa sesuai dengan aksinya yang beragam ${ }^{19}$.

Fakhruddin menyebutkan beberapa dalil mengenai adanya kesatuan jiwa tersebut, antara lain:

1. Sesungguhnya emosi merupakan situasi psikis yang terjadi ketika berusaha mencegah sesuatu yang menafikan, sedangkan syahwat merupakan kondisi psikis yang terjadi ketika berusaha mencari yang sesuai. Sebagaimana diketahui, bahwa mencegah sesuatu yang menafikan dan mencari sesuatu yang sesuai disyaratkan adanya perasaan terhadap sesuatu yang menafikan dan sesuatu yang sesuai. Dengan demikian, daya emosi yang merupakan daya pencegah untuk sesuatu yang menaifkan, jika tidak memiliki perasaan terhadap adanya sesuatu yang menafikan, maka kedudukannya adalah sebagai pencegah bagi yang menafikan atas dasar ikhtiar. Setelah itu ditetapkan bahwa orang yang marah pasti melakukan proses persepsi, begitu pula orang yang bersyahwat pasti melakukan proses persepsi. Maka, dengan argumen yang kuat ini ditetapkan bahwa persepsi, emosi dan syahwat merupakan tiga sifat untuk satu zat dan tidak mungkin menjadi tiga sifat untuk tiga zat yang berbeda.

\footnotetext{
${ }^{18}$ Kitab an-Nafs wa ar-Ruh wa Syarh Quwahuma, h. 159.

${ }^{19}$ Al-Mathalib al-Aliyah Min al-Ilm al-Ilahi, h. 159.
} 
Jurnal Pemikiran Konstruktif Bidang Filsafat dan Dakwah ISSN 1907 - 0993

E ISSN $2442-8264$

Vol. 16 No. 2, Desember 2019

2. Mengasumsikan dua substansi yang berdiri sendiri, yaitu setiap substansi berdiri sendiri dengan aksinya yang khusus, maka kesibukan salah satu dari keduanya dengan aksinya yang khusus tidak mungkin menjadi pencegah bagi yang lain untuk bersibuk-sibuk dengan aksinya yang khusus pula. Jika demikian, maka dapat dikatakan, "Jika kedudukan berpikir sebagai substansi pertama, lalu kedudukan emosi sebagai substansi kedua, dan kedudukan syahwat sebagai substansi ketiga, maka kesibukan daya emosi dengan aksinya pasti tidak akan menjadi penghalang bagi daya syahwat untuk bersibuk-sibuk dengan aksinya, dan tidak juga sebaliknya. Tetapi ketika kesibukan manusia dengan syahwat mencegahnya untuk sibuk dengan emosi, atau sebaliknya, maka hal itu menunjukkan bahwa ketiga aksi tersebut, yaitu pikiran, emosi, dan syahwat merupakan aksi-aksi untuk satu substansi, dan bukan aksi-aksi untuk tiga substansi yang berdiri sendiri.

3. Mempersepsi sesuatu, maka persepsi itu dapat menjadi merupakan sebab munculnya syahwat atau emosi. Tetapi jika substansi yang mempersepsi sesuatu berbeda dengan substansi yang bersyahwat, maka persepsi kita terhadap sesuatu itu tidak akan menimbulkan terjadinya syahwat atau terjadinya emosi. Persepsi sesuatu menimbulkan terjadinya syahwat atau terjadinya emosi, karena orang yang mempersepsi adalah juga orang yang bersyahwat dan emosi ${ }^{20}$.

\section{Kenikmatan dan Penderitaan}

Ar-Razi mengatakan bahwa tidak ada sesuatu yang disukai karena zatnya, kecuali kenikmatan dan kesempurnaan. Sebenarnya tidak ada perbedaan antara kenikmatan dengan kesempumaan, lantaran sesuatu yang lezat menjadi sebab untuk memperoleh kesempurnaan, atau sesuatu yang sempurna menjadi sesuatu yang

\footnotetext{
${ }^{20}$ Al-Mathalib al-Aliyah Min al-Ilm al-Ilahi, juz 7, h. 160.
} 


\section{FARABI}

Jurnal Pemikiran Konstruktif Bidang Filsafat dan Dakwah

ISSN $1907-0993$

E ISSN $2442-8264$

Vol. 16 No. 2, Desember 2019

nikmat; tetapi kita mengistilahkan sesuatu yang nikmat secara fisik disebut kenikmatan dan sesuatu yang nikmat secara ruhani disebut kesempurnaan ${ }^{21}$.

Selanjutnya, dia menyatakan bahwa sesuatu yang tidak disukai pada dirinya adalah penderitaan dan kekurangan. Sebenarnya tidak ada perbedaan di antara keduanya. Kesempurnaan adalah sesuatu yang disukai untuk dirinya dan dengan dirinya, lantaran ia merupakan kesempurnaan. Sedangkan kekurangan adalah sesuatu yang tidak disukai dengan dirinya dan untuk dirinya, lantaran ia merupakan kekurangan.

Sebenarnya kenikmatan hanyalah usaha untuk mencegah penderitaan. Tidak ada makna kenikmatan makan, selain untuk mencegah penderitaan lapar; juga tidak ada makna kenikmatan pakaian, selain untuk mencegah penderitaan panas dan dingin. Jadi, hakikat kenikmatan adalah mencegah penderitaan. Dengan hal itu tampak jelas bahwa segala sesuatu yang dianggap orang sebagai kenikmatan sebenarnya bukanlah kenikmatan, melainkan suatu usaha untuk mencegah penderitaan. Jika kebutuhan terhadap sesuatu lebih kuat, maka kenikmatan yang dirasakan akan lebih kuat ketika sesuatu itu diperoleh. Sebaliknya, jika kebutuhan terhadap sesuatu lebih sedikit, maka kenikmatan yang dirasakan lebih lemah kendati sesuatu itu diperoleh.

Sesuatu yang nikmat jika bertahan dan berlanjut, maka ia tidak lagi menjadi sesuatu yang nikmat, karena pada keadaan yang berkelanjutan dan konstan emosi akan hilang, lalu perasaan menjadi tidak muncul. Jika perasaan tidak muncul, maka kenikmatan menjadi tidak ada. Demikian pula halnya jika sesuatu itu menyakitkan. Dengan demikian, kenikmatan dan penderitaan terjadi pada situasi transisi dari satu sisi ke sisi yang lain. Agaknya, ada kesamaan antara pendapat Fakhruddin ar-Razi dengan Abu Bakar ar-Razi tentang kenikmatan dan penderitaan. Keduanya sangat dipengaruhi oleh ide Plato yang ada di dalam buku.

4. Perihal Kebahagiaan

\footnotetext{
${ }^{21}$ Kitab an-Nafs wa ar Ruh wa Syarh Quwahuma, h. 20.
} 


\section{FARABI}

Jurnal Pemikiran Konstruktif Bidang Filsafat dan Dakwah

ISSN 1907 - 0993

E ISSN $2442-8264$

Vol. 16 No. 2, Desember 2019

Kebahagiaan manusia pada dasarnya bukan pada kemampuan memperoleh kenikmatan inderawi. Pasalnya, ia bersifat tidak abadi dan banyak bahaya yang ditimbulkannya jika orang tidak sering dalam mencapainya. Jadi, kenikmatan inderawi menegaskan makna kemanusiaan. Padahal, jika manusia mampu mencapai cahaya akal dan memahami alam gaib serta cahaya Ilahi, maka nilai kemanusiaannya akan makin tinggi. Sebaliknya, jika manusia disibukkan untuk memenuhi semua kenikmatan fisiknya maka daya rasionalnya menjadi tumpul, pintu makrifat tertutup, serta jiwa bahimiyah menjadi sesuatu yang dominan atasnya sementara jiwa imaniyahnya sirna.

Fakhruddin ar-Razi mengemukakan, "Sesungguhnya asal-usul kondisi manusia adalah kesibukannya dengan ma'rifatullah, konsistensinya untuk menaati Allah, dan keseriusannya dalam mencintai-Nya. Kesibukan manusia untuk memenuhi berbagai kenikmatan fisik dan keindahan inderawi menghalanginya untuk beribadah dan berzikir. Jika pengetahuan itu merupakan tingkatan tertinggi pada makhluk dan kenikmatan inderawi merupakan penghalangnya, maka kenikmatan inderawi merupakan sesuatu yang paling buruk dari sisi kepentingannya."

Pencapaian kenikmatan fisik dibutuhkan adanya hubungan jiwa dengan badan, yaitu hubungan yang terputus. Pasalnya, hubungan yang terputus semacam ini akan mencegahnya untuk mencapai kenikmatan fisik. Sebaliknya, kesibukan jiwa untuk mencari kesempurnaan ilmu merupakan suatu kenikmatan pada saat sekarang dan kebahagiaan pada masa yang akan datang. Sebab, penerimaan jiwa terhadap aljalayd al qudsiyah danal-ma'drifal-ildhiyah tidak berdasarkan pada ketergantungan jiwa dengan badan, bahkan ketergantungan tersebut menjadi penghalang untuk mencapai kesempurnaan jiwa. Jika ketergantungan itu terputus, maka al-jaldyd alildhiyah akan memancar.' Jadi, kebahagiaan manusia terletak pada mengarahnya ruh menuju alam yang paling tinggi dan menghindarnya dari alam yang paling rendah. Sesungguhnya orang-orang yang berorientasi ke alam kudus akan menemukan 
Jurnal Pemikiran Konstruktif Bidang Filsafat dan Dakwah

ISSN $1907-0993$

E ISSN $2442-8264$

Vol. 16 No. 2, Desember 2019

keabadian tanpa kefanaan, keagungan tanpa kehinaan, kenikmatan tanpa penderitaan, dan rasa aman tanpa rasa takut.

Fakhruddin ar-Razi membagi jiwa berdasarkan orientasi ruh ke alam paling tinggi atau alam paling rendah atau hubungan di antara keduanya menjadi tiga kelompok, yaitu:

1. Kelompok tertinggi adalah orang-orang yang mendapatkan sebutan as-sabiqin (kaum terdahulu) dari al-Qur'an yang menyebutkan: Dan orang-orang yang paling dahulu beriman, merekalah yang paling dulu (masuk surga). (QS. alWaqi'ah: 10). Mereka itulah orang-orang yang berorientasi ke alam Ilahi dan tenggelam di dalam cahaya shamdaniyah dan pengetahuan ilahiah.

2. Kelompok pertengahan adalah kelompok orang yang jiwanya oleh Al-Qur'an disebut dengan orang-orang kanan yang moderat. Mereka adalah orang-orang yang kadang-kadang dapat mencapai alam tertinggi dengan 'ubudiyah dan ketundukan, dan kadang-kadang ke alam terendah dengan pengaturan dan tindakan.

3. Kelompok ketiga adalah orang-orang yang berorientasi ke alam yang paling rendah dan tenggelam dalam pencarian sesuatu untuk dirinya. Al-Qur'an menyebut mereka golongan kiri dan zalim.

\section{Memperbaiki Akhlak Tercela}

Fakhruddin ar-Razi sangat concern untuk menganalisis beberapa akhlak tercela dengan tujuan untuk mengetahui sebab-sebabnya dan menjelaskan metode terapinya. Di antara akhlak tercela yang dibahas adalah sifat bakhil yang akan kami sebutkan sebagai satu contoh menjelaskan strategi-strateginya dalam menganalisis akhlak tercela dan metode terapinya.

\section{Sifat Bakhil (Kikir)}

Fakhruddin ar-Razi membedakan antara ambisius dan bakhil. Ambisius adalah usaha total untuk memperoleh kekayaan ketika tidak ada atau ketika jumlahnya sedikit; sedangkan bakhil adalah usaha total untuk mempertahankan 
Jurnal Pemikiran Konstruktif Bidang Filsafat dan Dakwah

ISSN $1907-0993$

E ISSN $2442-8264$

Vol. 16 No. 2, Desember 2019

kekayaan ketika kekayaan tersebut ada. Dengan demikian, cinta harta terjadi dalam dua hal: pertama, kesukaan untuk mengumpulkan dan menghasilkan harta yang disebut ambisius; dan kedua, kesukaan untuk mempertahankannya yang disebut bakhil $^{22}$. Sifat bakhil muncul karena terlalu cinta kepada dunia. Ia meyakini bahwa harta bendanyalah yang menyelamatkan hidupnya baik di dunia maupun di akhirat. Padahal harta yang sesungguhnya adalah harta yang ia sedekahkan kepada orang lain, harta yang dinikmatinya sendiri akan lenyap seiring dengan hilangnya kenikmatan dunia. Sedangkan harta yang ia sedekahkan akan kekal nikmatnya kelak di akhirat. ${ }^{23}$

Terapi sifat bakhil dapat dilakukan dengan dua metode, yaitu metode ilmu dan metode praktik. Dalam hal ini, ar-Razi mengikuti ide al-Ghazali yang mewasiatkan untuk melakukan terapi akhlak tercela dengan metode ilmu dan praktik. Fakhruddin ar-Razi banyak dipengaruhi oleh al-Ghazali sebelumnya tentang terapi sifat bakhil, dan banyak mengambil pendapatnya tentang topik tersebut ${ }^{24}$.

6. Terapi Bakhil dengan Metode Ilmu

Terapi sifat bakhil dengan metode ilmu dapat dilakukan dengan beberapa cara, di antaranya ${ }^{25}$ :

- Selalu mengingat kematian, merenungi kematian orang lain, dan merenungi bahwa manusia tidak dapat memanfaatkan kekayaan, kecuali semasa hidupnya. la harus mengurangi kebutuhannya, sehingga ambisinya untuk memperoleh harta yang memenuhi kebutuhankebutuhannya akan berkurang.

- Merenungi ayat-ayat dan hadis-hadis yang mencela sifat bakhil, memuji sifat dermawan, menjanjikan pahala yang besar bagi orang yang dermawan, serta memberi ancaman hukuman bagi orang yang bakhil.

\footnotetext{
${ }^{22}$ Kitab an-Nafs wa ar Ruh wa syarh Quwahuma, h. 113.

${ }^{23}$ https://www.muslimpintar.com/pengertian-sifat-bakhil-kikir-dan-akibat-sifat-bakhil/

${ }^{24}$ Bandingkan pendapat al-Ghazali tentang sifat bakhil dalam Ihya', Ulumuddin, op. cit., juz 3, h. 261. 261-263 dengan pendapat Fakruddin ar-Razi di dalam buku an-Nafs wa ar-Ruh wa Syarh Quwahuma, h. 114-123.

${ }^{25}$ An-Nafs wa ar-Ruh wa Syarh Quwahuma, h. 114-121.
} 
Jurnal Pemikiran Konstruktif Bidang Filsafat dan Dakwah ISSN $1907-0993$

E ISSN $2442-8264$

Vol. 16 No. 2, Desember 2019

- Banyak merenungi kondisi kaum yang bakhil, bagaimana orang-orang menjauhi dan mencela mereka. Sehingga pada saat itu ia akan tahu hakikat perasaan orang lain terhadap dirinya.

- Hendaknya ia mengetahui bahwa tidak ada cara untuk memanfaatkan harta kecuali dengan menginfakkannya. Manfaat harta secara fisik sangat sedikit dan untuk memperolehnya tidak memerlukan biaya yang banyak, sementara manfaat secara ruhani juga tidak ada.

- Kadang-kadang orang bakhil mengalami kondisi kehilangan harta dan pada saat itu ia tidak mendapatkan pujian dari orang lain dan pahala dari Allah. Tetapi jika orang menafkahkan hartanya dalam kebajikan, maka ia akan mendapatkan pujian dari orang lain dan balasan pahala dari Allah

- Sesungguhnya orang yang bakhil bagaikan tawanan yang dikuasai oleh cinta harta, tetapi jika ia mampu berinfak, maka dialah penguasa harta. Ketahuilah, kedudukan manusia sebagai penguasa harta lebih baik daripada kedudukannya sebagai orang yang dikuasai harta.

- Jika orang bakhil meninggal dunia, maka ia mewarisi hartanya untuk orang lain. Mereka pasti akan menafkahkannya untuk kepentingan diri mereka sendiri. Orang lain akan selalu mencelanya. Jadi, ia hanya mendapatkan celaan di dunia dan siksaan di akhirat karena hartanya.

- Orang yang dermawan sangat disukai semua orang dan orang bakhil sangat dibenci. Orang yang dermawan mengeluarkan hartanya dan menguasai ruh (hati) semua orang, sedangkan orang bakhil mempertahankan hartanya dan tidak dapat menguasai ruh (hati) orang lain. Ruh manusia berasal dari substansi malaikat, sedangkan emas dan perak berasal dari benda-benda mati. Oleh karena itu, perbedaan antara keduanya sangat besar.

- Selalu bersifat qanaah akan membuat orang tidak membutuhkan sesuatu. Sedangkan menikmati kenikmatan dunia akan membuat orang selalu 
Jurnal Pemikiran Konstruktif Bidang Filsafat dan Dakwah ISSN $1907-0993$

E ISSN $2442-8264$

Vol. 16 No. 2, Desember 2019

membutuhkannya. Kondisi tidak membutuhkan sesuatu lebih sempurna daripada kondisi yang membutuhkan sesuatu. Pasalnya, yang pertama merupakan sifat Allah, dan kedua sifat makhluk.

- Orang kaya membutuhkan usaha yang sungguh-sungguh untuk menjaga hartanya dari segala bencana dan kerusakan. Bahkan, jika hartanya hilang, ia merasa sangat sedih; dan jika tidak rusak, maka ia akan selalu mengalami ketakutan dan kelelahan untuk menjaganya. Sebaliknya, orang yang terbebas dari harta karena memperoleh kesempurnaan jiwa, maka ia terbebas dari ketakutan tersebut.

Sesungguhnya pengetahuan tentang semua hakikat di atas dapat mengubah pandangan orang yang bakhil terhadap harta dan mengurangi ambisinya untuk menyimpannya dan tidak menginfakkannya, sehingga ia terbebas dari sifat bakhil. Demikianlah, kita melihat Fakhruddin ar-Razi sama seperti al-Kindi, Abu Bakar arRazi, Miskawaih dan al-Ghazali yang telah melampaui para psikolog modern penganut aliran terapi behavioral-kognitif.

\section{Terapi Sifat Bakhil dengan Metode Praktik}

Fakhruddin ar-Razi menyebutkan beberapa cara yang dapat digunakan untuk mengatasi sifat bakhil dengan metode praktik. Di antaranya adalah sebagai berikut.

- Bergaul dengan kaum miskin dan menghindari pergaulan dengan orang kaya. Sebab, bergaul dengan kaum miskin yang selalu beribadah kepada Allah dapat mengurangi kecenderungan manusia untuk meraih kekayaan.

- Jika orang yang bakhil merenungi keburukan sifat bakhil dan kebaikan silat dermawan yang telah kami sebutkan sebelumnya, maka ia pasti cenderung untuk memilih kebaikan. Oleh karenanya, pada saat itu ia akan segera mengeluarkan harta dan berbuat baik dengannya sebelum mendapatkan halangan dan setan.

- Mencari seorang guru yang dapat membebaskannya dari segala sesuatu yang membuat hatinya tergantung. 


\section{FARABI}

Jurnal Pemikiran Konstruktif Bidang Filsafat dan Dakwah

ISSN 1907 - 0993

E ISSN $2442-8264$

Vol. 16 No. 2, Desember 2019

- Sesungguhnya sifat bakhil merupakan keasyikan yang berlebihan terhadap harta. Jika keasyikan terlalu berlebihan, maka akan menjadi penyakit yang parah. Obatnya yang terbaik adalah menjauhi sesuatu yang membuatnya asyik dan tempatnya. Demikian juga dengan cinta harta. Penyakit cinta harta dapat diatasi dengan menginfakkannya, sehingga keasyikannya terhadap harta hilang dari hatinya yang kemudian dapat menghilangkan sifat bakhil. Jadi, terapi bakhil adalah memperbanyak infak harta. Tentang hal ini, Fakhruddin ar-Razi menyebutkan satu kaidah umum, yaitu "Sesungguhnya banyaknya tindakan akan menguatkan sifat dan ketiadaan tindakan akan melemahkan sifat tersebut ${ }^{26}$.

Berdasarkan hal di atas, maka mempertahankan harta yang terlalu berlebihan akan menguatkan sifat bakhil, sedangkan sering berinfak dapat melemahkan sifat bakhil. Sebenarnya metode terapi ini merupakan terapi akhlak tercela dengan lawannya (recipmcal inhibition), sebagaimana anjuran al-Ghazali sebelumnya. Hal itu terlihat jelas dari pendapat Fakhruddin ar-Razi yang ia kutip dari al-Ghazali: "Walhasil, ahli terapi akhlak tercela memberdayakan sebagian akhlak atas akhlak yang lain, sehingga ia memberdayakan syahwat atas emosi serta dengan lawannya.

Agaknya metode terapi sifat bakhil dengan secara praktis sangat mirip dengan metode yang digunakan oleh para psikolog modem dalam mengatasi gangguan perilaku terutama terapi reciprocal inhibition. Fakhruddin ar-Razi dan alGhazali telah mendahului para psikolog modern dalam menggunakan metode ini untuk menanggulangi gangguan perilaku. Sebelumnya telah dijelaskan hal ini secara rinci ketika membahas tentang al-Ghazali.

\section{Kebahagiaan}

\section{Ilmu Firasat}

Fakhruddin ar-Razi sangat concern dengan persoalan "firasat". Berdasarkan definisinya, firasat adalah mencari makna melalui berbagai kondisi nyata atas akhlak

\footnotetext{
${ }^{26}$ Kitab an-Nafs wa ar-Ruh wa Syarh Quwahuma, h. 123.
} 


\section{FARABI}

Jurnal Pemikiran Konstruktif Bidang Filsafat dan Dakwah

ISSN 1907 - 0993

E ISSN $2442-8264$

Vol. 16 No. 2, Desember 2019

batin. Secara kebahasaan, firasat berarti keahlian dalam mengetahui berbagai kondisi batin melalui kondisi lahir. Abu Qasim ar-Raghib berkata, "Sesungguhnya kata firasat diambil dari ucapan orang Arab farasa as-sab'u asy-sydta (binatang buas memangsa domba). Dengan demikian, firasat adalah mengambil pengetahuan dengan cara tertentu.

Di dalam hadis Nabi saw., disebutkan, "Hati-hatilah terhadap firasat orang mukmin karena ia melihat dengan nur Allah." Kemudian Beliau membaca firman Allah:... sesungguhnya hal itu merupakan tanda-tanda bagi orang-orang yang mutawassimin (orang-orang yang berfirasat kuat).

Dengan demikian, firasat adalah cahaya yang dilimpahkan Allah di dalam hati orang yang Dia kehendaki, sehingga ia dapat melihat perkara-perkara yang tersembunyi. Ar-Razi dianggap sebagai perintis dalam bidang ilmu firasat pasca Aristoieles. Di dalam buku ar-Razi tentang firasat dia telah meringkas buku Aristoteles dengan berbagai penambahan penting. Beberapa ilmuwan Muslim lainnya telah menulis topik firasat, di antaranya adalah Muhammad bin ash-Shufi yang mengarang buku berjudul as-Siyasah fi' Ilm al-Firasah dan Ibnu Qayyim al-Jauziyah yang juga membahas topik firasat di dalam bukunya yang berjudul Madarij asSalikin.

Di awal abad ke-19, Franz Joseph Gall (1758-1828) dan muridnya, Spurzheim (1832-1776 M), keduanya dari Jerman, melakukan penelitian tentang hubungan bentuk tengkorak dengan kemampuan akal dan karakteristik jiwa. Keduanya membangun beberapa hipotesis, antara lain:

1. Sesungguhnya kemampuan rasio dari karakteristik jiwa berpusat di daerah tertentu dari otak.

2. Sesungguhnya tingkat perkembangan kemampuan rasio dan karakteristik jiwa bergantung pada tingkat pertumbuhan bagian-bagian otak yang menjadi pusatnya. 
Jurnal Pemikiran Konstruktif Bidang Filsafat dan Dakwah ISSN 1907 - 0993

E ISSN $2442-8264$

Vol. 16 No. 2, Desember 2019

3. Sesungguhnya tambahan pertumbuhan di semua bagian otak terjadi karena tekanan pada dinding tengkorak yang berhadapan.

\section{Pemikiran Abu Bakar ar-Razi tetang kesehatan mental Islami}

a. Cinta dan asmara

Menurut ar-Razi orang yang kasmaran menurutnya adalah orang yang umumnya hanya membayangkan kenikmatan yang akan diperoleh tanpa akan terpetik di hatinya penderitaan dan sakit yang akan dialami dalam waktu yang panjang.

b. Ujub

Ujub muncul ketika seseorang memandang lebih dan lebih terhadap dirinya, sehingga dia menginginkan pujian yang melebihi seharusnya. Sifat ini membuat seseorang memandang orang lain tidak lebih utama dari pada dirinya. Sifat ujub ini dapat diatasi dengan cara mengenal aib sendiri melalui orang lain yang dekat dengan nya.

c. Iri

Keirihatian merupakan perpaduan kekiran dan ketamakan. Orang yang iri hati adalah orang yang mersa sedih bila orang lain memperoleh suatu kebaikan, meski tak keburukan pun menimpa dirinya. Bila keburukan yang menimpa dirinya, maka yang muncul bukan hanya keirihatian tetapi permusuhan. Bagi orang yang menyenangkan dirinya dengan yang dibutuhkannya, maka di dalam jiwanya tiada tempat bagi keirihatiannya.

d. Kemarahan dan dusta

Kemarahan muncul dari binatang agar mereka dapat melakukan pembelaan terhadap bahaya yang mengancam. Bila berlebihan hal ini sangat berbahaya bagi mereka dusta adalah suatu kebiasan buruk.

e. Kikir dan tamak 
Jurnal Pemikiran Konstruktif Bidang Filsafat dan Dakwah

ISSN $1907-0993$

E ISSN $2442-8264$

Vol. 16 No. 2, Desember 2019

Sifat kikir tidak dapat ditolak keseluruhannya nilainya terletak pada alasan melakukannya. $^{27}$

\section{KESIMPULAN}

Fakhruddin ar-Razi adalah seorang yang besar dan tidak tertandingi di zamannya (setelah al-Ghazali). Memiliki berbagai buku karangan tentang berbagai disiplin ilmu, di antaranya tafsir, ilmu kalam, ushul fiqih, hikmah ilmu debat, nahwu, sastra, kedokteran, teknik, psikologi, ilmu firasat, akhlak, dan ilmu tentang aliran dan golongan. Diperkirakan jumlah karangannya melebihi 200 buah. Ar-Razi mendefinisikan jiwa sebagai substansi yang berbeda dengan badan, terpisah secara esensial dan bergantung dengannya, secara pengaliran dan instruksi jiwa mempunyai tabiat, daya (daya tumbuhan, daya hewani, daya insani). Kenikmatan hanya usaha untuk mencegah penderitaan. Kebahagiaan adalah jika manusia mampu mencapai cahaya akal dan memahami alam gaib serta cahaya ilahi. Jadi kebahagiaan manusia terletak pada mengarahnya ruh memuja alam yang paling tinggi dan menghindarinya dari alam yang paling rendah.

\section{DAFTAR PUSTAKA}

Akbar, Muhammad. Jiwa Manusia menurut Fakhruddin ar-Razi, From: https://mujahiddakwah.com/2018/09/jiwa-manusia-menurut-fakhruddin-arRazi-adnin-armas-m-a/

Fathullah Khalif, Fakhruddin ar-Razi, Iskandariah: Danal Jamiat al Mishriyah, 1977. http://digilib.uinsby.ac.id/14424/4/Bab\%201.pdf https://alusttadz.blogspot.com/2012/05/daya-daya-jiwa-manusia.html https://image.slidesharecdn.com/gangguanjiwa-141208190207-conversiongate01/95/gangguan-jiwa-10-638.jpg?cb=1418065399

https://www.muslimpintar.com/pengertian-sifat-bakhil-kikir-dan-akibat-sifat-bakhil/

\footnotetext{
${ }^{27}$ https://www.academia.edu/37410773/MAKALAH_KESEHATAN_MENTAL.docx
} 
Jurnal Pemikiran Konstruktif Bidang Filsafat dan Dakwah ISSN 1907 - 0993

E ISSN $2442-8264$

Vol. 16 No. 2, Desember 2019

https://www.referensimakalah.com/2012/08/konsep-jiwa-menurut-ar-Razi.html

Jalaluddin, Abd. Ketenangan Jiwa menurut Fahr al-Din ar-Razi dalam Tafsir Mafatih al-Ghayb. Jakarta: Sekolah Tinggi Filsafat Islam Sadra Jakarta, 2018.From:

file:///C:/Users/Asus/AppData/Local/Packages/Microsoft.MicrosoftEdge_8

wekyb3d8bbwe/TempState/Downloads/2288-8385-1-PB\%20(1).pdf

Jiwa Manusia Menurut Fakhruddin ar-Razi. From https://insists.id/jiwa-manusia$\underline{\text { menurut-fakhruddin-ar-Razi/ }}$

Konsep Jiwa $\quad$ Menurut Fakhruddin ar-Razi from https://www.academia.edu/15616201/Konsep-Jiwa--Menurut-Fahruddin-ar$\underline{\text { Razy }}$

Raharjo, Dawam. Ensiklopedia al-Qur'an Tafsir berdasarkan Konsep-konsep Kunci. Cet. 1; Jakarta: Paramadina, 1996.

Saunima, Iqbal Abdul Rauf. Sekitar Filsafat Jiwa dan Manusia dari Ibnu Sina dalam Dawam Raharjo, Jakarta: Raja Grafindo, 2012.

Biografi Fakhr ad-Din ar-Razi - Filsuf Muslim, https://biografi-tokohternama.blogspot.com/2015/03/biografi-fakhr-ad-din-ar-razi-filsuf$\underline{\text { muslim.html }}$

https://www.academia.edu/37410773/MAKALAH_KESEHATAN_MENTAL.docx 